\title{
The Reform of Muslim Women's Rights in the Marriage Law of Indonesia and Malaysia
}

\author{
Robi'atul Adawiyah \\ The Islamic State University of Sultan Thaha Saifuddin Jambi, Indonesia
}

\begin{abstract}
The phenomenon of family law reform in the Islamic world which was driven by the Ottoman Empire in 1917 has inspired various Muslim-majority countries around the world, including Indonesia and Malaysia, to reform Islamic family law so that it is always in line with the situation and conditions of Muslims in each country. One of the main issues of family law reform in the Islamic world is concerning women's rights in Islamic marriage law. This study shows that Indonesian and Malaysian marriage law has given Muslim women in both countries a more equal position with men, as well as various rights that were never accepted by Muslim women in the classical period as contained in the traditional fiqh books. However, if it is viewed from the perspective of human rights and gender equality, the marriage laws of Indonesia and Malaysia have not fully provided protection for the upholding of a just law for women in the country. Three important things must be done: first, change the perspective of Muslims that the contextualization of Islamic family law for the benefit of the ummah is not contrary to Islamic law but in line with the objectives of Islamic law (maqashid syarah). Second, the importance of accelerating changes in KHI status from mere Presidential Instruction to the Law on material for Religious Courts. Third, the need to revise the substance of the material for a fair and democratic Marriage Law based on Islamic teachings that prioritize human values.
\end{abstract}

Keywords: Reform, Family Law, Indonesia, Malaysia

DOI: $10.7176 / J L P G / 82-15$

\section{Introduction}

At the beginning of the 20th century, an important phenomenon emerged in the Islamic world, namely the enthusiasm and efforts to reform and renew family law in predominantly Muslim countries. The first Muslim country to renew its family law so that it was in line with the social development of the Muslim community at that time was the Ottoman Empire.

In 1876, to modernize its judicial system, the Ottoman Caliphate compiled a codification of Islamic law in the form of a legislation so that it could be easily referred to and taken into law. This codification is known as Majallat al-Ahkam al-Adliyyah, and it is the first Civil Law in Turkey even in the Islamic world. However Majallah al-Ahkam al-Adliyah has one drawback, namely that there is no regulation regarding family law (marriage and inheritance). Family law still refers directly to the books of the fiqh of the Hanafi school (Nasution, 2011: 27-29). The problem is that in the Hanafi school, a wife has no right to file divorce, and divorce is only the authority of the husband (Anderson, 1994: 57-58).

According to the Hanafi school, a wife can only get the cancellation of a marriage from a judge if it turns out that her husband is impotent. She is also only allowed to file a divorce in the case that her husband becomes a missing person (maqfud) when it is estimated that the husband has reached the age of more than ninety years. Moreover, a wife does not have legal tools to free herself from harmful marital ties and even to negotiate divorce with her husband to produce divorce with mutual agreement.

On the other hand, the Maliki school is the most liberal school in this regard, allowing a wife to file a claim on the grounds that her husband is cruel, unwilling or unable to provide her with a living, defect or leave home, or suffer a severe illness which if the marriage continues will endanger the wife. Therefore, in 1915 two royal decrees were issued which reformed matrimonial law (related to marriage) in the Hanafi school which was related to women's rights to divorce. In the Decree, the principle of takhayyur (eclectic choice) is used, by taking the source of the Maliki and Hambali schools, it is stated that women are permitted to seek divorce on the basis of the abandonment of their husbands or because of their illness (Muzdhar, 2003: 39). In the first case, the reason (hujjah) of Maliki was used as the basis for the decree. While in the second case, the Hambali doctrine was taken (Coulson, 1964: 216).

The law on family rights in 1915 was later refined and promulgated in 1917 under the name Qanun Qarar al-Huquq al-ilah Is Al-Uthmaniyyah (The Ottoman Law of Family Rights) or the Law on Family Rights. This is the first promulgated family law in the Islamic world, consisting of 156 articles governing individual law and family law (but not inheritance, wills and grants). This law does not only originate from the Hanafi school of jurisprudence, but also comes from other schools of fiqh such as the Maliki, Shafi'i, Hambali schools, even from the opinion of extinct schools such as the Abi Laila school and the Sufyan Ats-Sauri school by choosing things. which is in accordance with the conditions of the times (Supriyadi, 2010: 124). Thus, the enactment of this Law was encouraged by the spirit of takhayyur, namely by choosing one of the opinions of the existing school of fiqh. 
The birth of the Ottoman Law of Family Right in 1917 was a milestone in the reformation of family law in the Islamic world. Tahir Mahmood termed this point as the point of departure from conventional fiqh (classic) to modern legislation (Magazine of Religious Courts, 2015: 8). Islamic family law, which in the past only existed in various fiqh books in a country, through the Ottoman Law of Family Right in 1917, was reborn seriously and systematically through a modern constitution. Turkey's reform efforts were followed by various Muslim-populated countries throughout the world, including Indonesia and Malaysia.

According to Tahir Mahmmod (1972: 11-12), there are 13 things that are undergoing renewal in modern Muslim family law when compared to the concept of traditional fiqh. One of them is related to women's rights in marriage. Marital rights are one of the important indicators for the status of women in society. The concept of traditional fiqh tends to place women in a weak position as the second creation and the second sex. The Islamic world has defined women for centuries as the second rate committees which are socially inferior to men. Since it was created, men have been given God quwwah (strength) or qudrah (ability), and virtues that women do not have. Therefore, women must submit to male power and their hegemony for the smoothness and sustainability of family life. This unequal understanding has caused a woman to lose her rights as a human, even prone to experiencing violence in relationships with her closest people (Mutahhari, 1981: 30).

In subsequent developments, the birth of democratic politics and the emergence of socialist and capitalist economic systems in the West gave new awareness to the rights and position of women. This then influenced the thinking of modern Muslim intellectuals who had begun to have a lot of contact with western scholarship and had awareness on several global issues such as: justice, human rights and gender. Muhammad Abduh (1849-1905), Qasim Amin (1863-1908), Mustafa al-Maraghi (1881-1945), until Fazlur Rahman (1919-1988) felt uneasy and dissatisfied with the interpretations of the previous scholars regarding several aspects of Islamic law especially regarding the rights and position of women in Islamic marriage. From this point on, new ideas emerge to reform women's rights in marriage.

According to reformers, Islam does not discriminate between men and women. In the Qur'an it has been explained that humans have the same position in the eyes of God, whether male or female. Both are created from one nafs (living entity), where one does not have an advantage over the other (QS. An-Nisa: 1). The Qur'an also never mentions that Eve was created from the ribs of the Prophet Adam, so that there was an assumption that the position and status of women was lower than that of men. The Qu'ran has even revealed a major revolution with its statement in QS. Al-Baqarah: 228 "lahunna mitslul ladzi aih alaihinna" (The rights of the wife are equal to the rights of the husband). On that basis, the principles of the Qu'ran against husbands and wives are the same, where the rights of the wife are recognized as equal to the rights of the husband. Even if there is a specificity for men who are mentioned by Allah in the Qu'ran as a husband at a higher level than a wife (QS al-Baqarah/2: 228), a male leader for women (Surat an-Nisa'/4: 34), men get more inheritance than women (QS an-Nisa'/4: 11 and 176), men are effective witnesses (QS al-Baqarah/2: 282), may polygamy (QS an-Nisa'/4: 3) and so on, it does not make men become the main servants when compared to women. This advantage is given in its capacity as a member of the community that has a broader public and social role when the Qu'ran is revealed (Umar, 2001: 226-227).

Here it can be seen reinterpretation of the meaning of the Qu'ran verses relating to the rights and position of women in Islam. Initial understanding that is discriminatory and contains injustice has moved to a more just and moderate understanding. This is indeed influenced by modern life situations which provide equal opportunities for men and women to achieve achievements based on the skills they have. The same responsibility between men and women results in them getting the same rights in the professional world and then influencing the relationship of husband and wife in marriage.

On the other hand, various realities show that there are still many discriminations and injustices affecting women in Muslim countries without exception in Indonesia. Although Law No. 1 of 1974 Regarding Marriage and Compilation of Islamic Law (KHI) by some circles is often referred to as a milestone in the renewal of Islamic law in Indonesia, there are still various norms that are contrary to the principle of Protection of Human Rights and equality of citizens before the law. Indonesian marriage law still holds problems of injustice related to women's rights starting from the provision that women should not be witnesses to marriage even though the reality of Indonesian women may be judges and even presidents, the inability of mothers to become guardians of marriage because she is a woman even though she is the closest and most responsible person answer to their children after the death of their husband, the number of cases of polygamy without court permission which is very detrimental to the wife, unilateral divorce by the husband outside the court, underage marriage, sirri marriage, mut'ah marriage (contract marriage), forced marriage, up to the number of cases of domestic violence (domestic violence). In addition, the absence of norms related to sanctions of violating marital law also shows that Indonesian marriage law has not fully provided legal protection for women's rights in Indonesia.

In addition, the facts also show that the application of Islamic law in various countries with Muslim populations has different patterns and systems from one another. In addition, the domination of the ruler or "political will" also greatly influences the legal policies of a country. Therefore the implementation of Islamic law in Muslim countries lies not only in how many adherents of Islam are but also determined by the system developed 
by the country.

Therefore, this study takes the setting of Indonesian and Malaysian marriage law. Because as two countries that are very close geographically, historically, and culturally in the Southeast Asia region, Indonesia and Malaysia certainly have many similarities, such as having common customs and Malay races, equally having a population with Muslims as the majority and the same the same uses Islamic law, especially the Shafi'i school (Mutohhar, 2003: 2). However, even though both are dominated by Muslims, Indonesian Islam is different in style and tendency to Islam in Malaysia.

According to data from the Central Statistics Agency, the number of Indonesian Muslim population is $87,18 \%$ of the total population of Indonesia. Nevertheless, the two largest organizations, NU and Muhammadiyah, firmly rejected the establishment of an Islamic state (http://rahmatislamku.blogspot.co.id). In contrast, Malaysian Muslims account for only $60 \%$ of the total population, but constitutionally, Malaysia declares itself as an Islamic state and wants to impose Islamic Sharia (Kamal, 2004: 157).

Likewise, the issue of Islamic law that developed by the two countries is also different. The Indonesian Muslim community was shocked by the controversy over the draft Law on Legal Material in the Religious Courts through the submission of the Counter Legal Draft (CLD) Compilation of Islamic Law (KHI) based on human rights and gender by the Ministry of Religion's Gender Mainstreaming Working Group (now: Ministry of Religion) chaired by Musdah Mulia. On the contrary, Malaysia has been enlivened by the rejection of women's rights groups against the Draft Amendment to the Islamic Family Law 2005 because the substance of the draft amendment is considered to discriminate against women such as the ease of polygamy requirements to the prohibition of the use of joint property by their own wife or husband (Rofi'i, ejournal.iainpurwokerto.ac.id). According to the author, from these cases, it can be seen that the direction of Indonesian Islam tends to be moderate and even liberal while Malaysia increasingly tends to be conservative.

\section{Formulation of Problem}

2.1 How is women's rights reform in Indonesian marriage law?

2.2 How is women's rights reform in Malaysian marriage law?

2.3 What are the differences and similarities, the advantages and disadvantages of women's rights reform in Indonesian and Malaysian marriage law?

\section{Research Design/Method of Research}

The type of research is normative juridical research which focused on examining legal principles, legal synchronization, legal history and comparative law (Marzuki, 2005: p. 172). There are four approaches used. First, the historical approach, Second, the conceptual approach, Third, the normative approach, and the fourth, the comparative approach. The legal materials used in this study include: Law No. 1 of 1974 concerning Marriage in Indonesia, Deed of Communal Territorial Islamic Family Law (Deed 303 of 198a), Enactment of the Melaka State Islamic Family Law (Enactment 12 of 2002), Government Regulation No. 9 of 1975 concerning the Implementation of Law NO. 1 of 1974, Presidential Instruction No.1 of 1991 concerning Compilation of Islamic Law in Indonesia.

At the beginning of this study, researcher adhered to the results of research by Khoiruddi Nasution in his work entitled Women's Status in Southeast Asia: A Study of the Legislation of Contemporary Muslim Marriage in Indonesia and Malaysia (2002), that in connection with the existence of Malaysia as a federal state, Malaysia does not have National Muslim Marriage Law. Each state in Malaysia has its own law. The Islamic Family Law in Malaysia can be grouped into two major groups. First, the Act that follows the Partnership Deed, namely (1) Selangor, (2) Negeri Sembilan, (3) Penang, (4) Pahang, (5) Perlis, (6) Terengganu, (7) Serawak, (8) Sabah, although some adjustments remain. Second are (1) Kelantan, (2) Johor, (3) Melaka and (4) Kedah. These two groups still have many similarities, although there are indeed quite striking differences between the two groups (Nasution, 2003: 22). Thus, the researcher determined 2 states as the object of research, namely the Kuala Lumpur Guild Area representing countries that followed the partnership deed and the Melaka State as the countries representing countries not following the Partnership Act.

\section{Findings}

\subsection{Reform of women's rights in Indonesian marriage law.}

Efforts to reform Indonesian family law, especially marriage law, have begun since the Dutch colonial period. Due to the many infamies occurred in marriages among Muslims, such as marriages of children (underage), forced marriages, polygamy, arbitrary divorce from husbands, in 1937, the Dutch East Indies government drafted a preliminary plan of registered marital ordinance. It regulates that; (a) a man is only allowed to marry one wife; (b) divorce only occurs with court permission; and (c) every marriage must be recorded in a civil registry. However, the Ordinance received many protests and rejections from Muslims because it was considered to be contrary to the dogma of Islam. By following the ordinance, it is clear that Muslims cannot do polygamy which according to their 
religious teachings is permissible. Husbands also cannot decide divorce by their own will as allowed by religion. Because of the many community opposition to the draft Ordinance, the Dutch government canceled its application. After independence, to overcome the high number of marital cases that disrupted the happiness and welfare of the family, President Soeharto on July 31, 1973, submitted a bill on national marriage to the House of Representatives in 1973. The bill had several objectives: First, legal unification to provide legal certainty in marital matters, because there was only judge made law before marriage legislation existed. Second, protecting the rights of women and at the same time fulfilling the expectations of women who have been fought mainly by women's organizations so that the state immediately has laws that regulate and protect marriages. Third, creating laws that are in accordance with the demands of the times.

This bill again received a strong reaction from the Muslim community. There are several articles that are considered to be contrary to the teachings of Islam (fiqh munakahat), including, the problem of marriage registration, the problem of minimum age limit of 21 years of marriage for men and 19 years for women, and joint property in marriage to the ability of interfaith marriages. Finally, a compromise of the law was reached with the approval of the Muslims which was then passed as a Law No. 1 of 1974 concerning Marriage.

It is Interesting to note with the enactment of Law No. 1 of 1974, that Islamic law entered a new phase with what is called the taqnin phase (enactment phase). There are many Islamic jurisprudence provisions regarding marriage transformed into the Law despite several modifications. Therefore, there are some religious leaders who say that the law can be categorized as the result of the new Indonesian Muslim ijtihad, which is still in the corridor of fiqh with the ta'lili and istislahi method. Therefore, Law No. 1 of 1974 concerning Marriage can still be said to be the Islamic Law and the material can be a discussion of fiqh. This is why, the birth of Law No. 1 of 1974 concerning marriage is worth mentioning as the first milestone in the renewal of Islamic family law in Indonesia.

For the implementation of the Law, the Government then issued Government Regulation (PP) 9 of 1975 as the implementing regulation of the Marriage Law. In addition, for matters not covered in the Marriage Law and the implementing regulation PP, the Government issued a Circular Letter of the Religious Courts No. B / 1/1735 dated February 18, 1958 that the judges in the religious court were advised by the government to use the 13 books of Islamic jurisprudence of the Shafi'i school as a guideline for legal references in deciding cases, namely (1) Bughyat al-Mustarsyidin; (2) al-Fara'id; (3) Fath al-Mu'in; (4) Al-Fiqh 'ala al-Mazahib al-arba'ah; (5) Fath alWahhab; (6) Hasiyah Kifayat al-Akhyar; (7) Mugni al-Muhtaj; (8) Qawanin al-Syar'iyyah li Sayyid Usman bin Yahya; (9) Qawanin al-Syar'iyyah li Sayyid Sodaqah Dahlan; (10) Qalyubi/Mahalli wa Syarhihi; (11) Syarqawi 'ala al-Tahrir; (12) Targhib al-Musytaq; and (13) Tuhfat al-Muhtaj.

Although materially the books are known for their validity, they do not solve the problem. The number of fiqh books hold by the judges' hand causes different decisions on the same issue, as the phrase said "different judge different sentences". Although both have the Syafi'i school, one scholar with another cleric still has frequent dissent. This caused legal uncertainty regarding cases decided by the Religious Courts. This condition is the background to the need for written Islamic family law to break the legal impasse. Then came the idea of compiling a Compilation of Islamic Law as an official reference for judges in the Religious Courts.

In the process of compiling The Compilation of Islamic Law (KHI), the Designation Team worked with 7 State Institute for Islamic Studies (IAIN) spread across Indonesia to study 38 kinds of fiqh books from various schools and to study the fatwas of mufti that developed in Indonesia, such as the fatwa of the Indonesian Ulema Council (MUI), Majelis Tarjih Muhammadiyah, Bathsul Masa'il Nahdlatul Ulama (NU) and so on. The drafting team of the Compilation of Islamic Law project also uses various jurisprudence decisions of the Religious Courts which have been compiled in 16 books. Then, interviews were conducted with the scholars who were scattered throughout Indonesia. To obtain legal systems/rules, it was done by comparing other Islamic countries such as Morocco (28 and 29 October 1986), Turkey (1st and 2nd). Next, after the Compilation of Islamic Law draft was compiled, a National Workshop was held to refine it which was attended by 124 participants from all over Indonesia consisting of the Chairmen of the Provincial Ulema Council, the Heads of the High Religion Court throughout Indonesia, several Chancellors of IAIN, several Deans of the Faculty of Sharia IAIN, a number of representatives of Islamic organizations, a number of ulemas and a number of Muslim scholars both in the regions and at the center, and also representatives of women's organizations. On this basis, Amir Syarifudin then considered the Workshop to be the culmination of the development of Indonesian fiqh thought and should be considered as a consensus (ijma') of Indonesian scholars, or at least in the Indonesian version of Bustanul Arifin "ijma". Finally, after going through a long debate, on June 10, 1991 the President of the Republic of Indonesia signed a Presidential Instruction Number 1 of 1991 as a material law for judges of the Religious Courts in all of Indonesia.

In 2004, the Government attempted to improve the legal status of KHI from Presidential Instruction (Inpres) to become a Law. Thus, an Agency was formed to prepare the bill. The agency succeeded in compiling the initial draft bill of Law on Applied Religious Courts (HTPA) in the Marriage Sector. Some of the contents of this bill are taken from the articles of KHI and Law No.1 of 1974 concerning Marriage. On the other hand, in response to the HTPA Bill, on October 4, 2004, the Ministry of Religion PUG Working Group formed by the Ministry of Religion 
launched a comparative text on the formulation of Islamic law called Counter Legal Draft Compilation of Islamic Law (CLD- KHI). This manuscript offers a number of thoughts on the reform of Islamic family law compiled in the Islamic Marriage Law Bill, the Islamic Inheritance Bill and the Islamic Representative Bill. The CLD-KHI book is published under the title "Renewal of Islamic Law: Counter Legal Draft Compilation of Islamic Law.

The KHI CLD Team offered 23 new articles which contained the contents of the Islamic family law reform towards the KHI which was deemed not in accordance with the times, such as the ability of women to marry themselves or to become marriage guardians, marriage witnesses, confession of adultery and extramarital children until 1: 1 division in the inheritance of boys and girls.

Changes are made because they take into account the cultural realities of Indonesian society which are different from Arabs and the Middle East. It also pay attention to the condition of many Indonesian women who are currently able to finance themselves and their families from their productive jobs and many women become public leaders, ranging from Village Heads, Heads Police to the president. For this framework of thinking, the CLD-KHI team interpreted the verses of the Koran and al-Hadith with the benefit approach, local wisdom, and maqashid al-syari'ah (the purpose of islamic law). This is reflected in the rules of the usul fiqh used in formulating the provisions of Islamic law. Thus, all provisions of Islamic law in CLD-KHI are actually explored and formulated from authoritative Islamic sources namely the Koran and al-Sunnah as well as classical Islamic intellectual treasures (the yellow book) through an assessment of the needs, experiences and traditions that live in Indonesian society and civilization of Muslim and Western societies in other countries.

However, the offer for renewal of CLD-KHI has generated more controversy in the community. Various blasphemy and rejection appeared. The MUI considers CLD-KHI to be heretical, bid'ah, taghyir (changing the authenticity of Islamic law) and manipulating al-Quran texts. The MUI then sent a letter of protest to the Minister of Religion affirming his view that CLD-KHI deviated from Islamic teachings. Finally, not more than one month, on October 26, 2004, the text of the renewal of Islamic family law was frozen by the next Minister of Religion, Muhammad Maftuh Basyuni.

Interestingly, some time later, precisely on Friday 17 February 2012, the Constitutional Court issued an important and revolutionary decision throughout the history of the Constitutional Court in this Republic. Based on a request for judicial review of Article 32 paragraph (2) of Law No. 1 of 1974 concerning Marriage submitted by the applicant Hj. Aisyah Mochtar a.k.a Machicha binti H. Mochtar Ibrahim and Muhammad Iqbal Ramadhan bin Moerdiono, the Constitutional Court ruled that all children born outside official marriage, including sirri marriages, infidelity and living together without marriage or saman leven, if it can be proven based on science and technology or other evidence has a blood relationship with his father, he has a civil relationship with his father and his father's family according to law.

Thus, it can be concluded that there are three objectives of marriage law reform in Indonesia, namely to improve the status of women, secondly, unification of marriage law, third, in response to the development and demands of the times.

The contents of women's rights reform in Indonesian marriage law are as follows:

a. The right to be asked for approval when it will be married

b. The right to be married only when the age is sufficiently mature is 19 years for men and 16 years for women

c. The right to be recognized has an equal position before the law, family and community relations.

d. The right to enter into a marriage agreement

e. Right to dowry.

f. The right to earn a livelihood.

g. The right to keep earning a living and a good relationship from the husband despite a domestic dispute.

h. The right to file a divorce to the Religious Court and only to be divorced through a court hearing.

i. Right to Mut'ah or money compensation for unilateral talaq.

j. The right to livelihood during the iddah period.

$\mathrm{k}$. The right to hadhanah to 12-year-old children both boys and girls.

1. The right to half shared property even if the husband is a civil servant (PNS), wife is entitled to a share of the husband's salary as well as the child's right to livelihood.

$\mathrm{m}$. If the husband passes away, before the inheritance is distributed, the wife has the right to half of her property with the deceased husband and the inheritance portion of the husband's inheritance.

\subsection{Reform of women's rights in Malaysian marriage law.}

In Southeast Asia, Malaysia is the first country to reform family law. Renewal of family law in Malaysia has begun since the country was still colonized by the British, namely the enactment of Mohammadan Marriage Ordinance No. V in 1880 in the strait states (Pinang, Melaka, Singapore), Registration of Muhammadan Marriages and Divorces Enactment 1885 for the State Allied Malay States (Perak, Selangor, Negeri Sembilan, and Pahang) and Divorce regulation in 1907 for non-allied Malay countries or sheltered countries (Kelantan, Terengganu, Perlis, Kedah, Johor). The law contains procedural law (recording and registration of marriages and divorces) in Malaysia. 
In addition, the UK also made regulations which made it difficult for polygamy to be carried out on the condition that it had to be carried out with court permission and gave punishment for violators.

Prior to British intervention, under the traditional system, Islamic law was administered according to local customs and Shari'a as understood and interpreted by the local wisdom chief and the headmen. Various problems of individuals, worship, and general are handled by the ulamas or leaders in the mosque by referring to the books of fiqh syafi'iyah. However, by the British, they are shifted and replaced by official cadets appointed by the government. The UK reorganized the court by creating a legal system based on their legal concepts and integrating the Religious Courts into the general framework of court administration. But it must be admitted, the interference of the British colonizers had led to the modernization of Islamic marriage law in Malaysia earlier.

After Malaysian independence, the Federal Government began to consider the importance of the unification of the Islamic Family Law in Malaysia, which is in harmony with the context of Malaysia, although it still refers to the Shafi'i school dominantly. Thus, a Committee was formed to draft Islamic Family Law that could be applied throughout the country. The results of this committee were then passed into the Islamic Family Law (Guild area) 1984 with Deed No. 303. Codification of the 1984 Alliance of Islamic Family Law Deed, internationally recognized as one of the most progressive codifications of Islamic family law in the Muslim world concerning rights and protection of women. However, each state in Malaysia made its own assessment of the 1984 Islamic Family Law draft (Guild area) which was then applied according to the understanding of religious law adopted by it, so that the purpose of unification had not yet been achieved. In general, codification in the form of the 80s decade Special Enactment provides more legal certainty, especially for the rights of women when compared to family law provisions that are still in the Pentadbiran Enakmen; where the details are left to the traditional fiqh authorities who are very vulnerable to diversity and uncertainty.

The Islamic Family Law in Malaysia compiled in the 70s and early 80s was made based on the al-siyasah alsyar'iyyah doctrine. The law was made more systematic and detailed. The contents of the law, many of which are loans or adoption of Indian and Pakistani Islamic family law that are Hanafi and Maliki. In the arrangement of polygamy, for example, the provisions regarding the application of polygamy contained in the taste of this new Islamic family have the same as the Pakistan Islamic Marriage Act 1960. In addition, there are regulations regarding penalties in the form of fines or prisons to teach the community. Thus the reforms made aim to facilitate the application of Islamic law and oversee the implementation process. For example the process of dissolution of divorce marriage must be brought to court by fulfilling certain procedures. In addition, the regulation on polygamy was also tightened. Husbands who want to have polygamy must get written permission from the Shariah Court. This effort was made with the aim of upholding justice among the wives, as well as to avoid the emergence of kemudhorotan over the first marriage and the next in accordance with the principles of saad al-zara'i.

In terms of procedural law, the influence of English law is very strong. For example related to relevance, accounting books, expert testimonies, proof of character, notification of hearings, proof of document content, proof of proof which all come from British procedural law. In some cases it still follows Islamic law, such as the issue of the necessity of two witnesses in litigation, different treatment of immature and non-Muslim witnesses. However, there is no difference between male and female witnesses in the Sharia judicial procedural law in Malaysia.

Efforts to uniform Islamic family law continue to be made. On May 6, 1988, the Syarak and Civil Law Technical Authority Office was formed, chaired by Professor Ahmad Ibrahim. This institution is in charge of reviewing the existing laws and adjusting them to Islamic law and formulating a draft law that can be used by the Court. This institution has formulated several proposals for amendments to several sections or clauses in the existing Islamic family law to ensure harmony and equality of rules in various countries. Thus, uniformity is done by changing some of the regulations in the Islamic Family Law "which are considered to be contrary to Islamic law" so that they are uniform with the same provisions that have been applied in several countries.

Among them are the rules of polygamy, which according to the rules of the Islamic Family Law of the Alliance 1984, article 123, that anyone who commits polygamy without the prior approval of the Religious Court may not be registered. This rule is felt to cause problems for the child and wife (the second). So at the urging of the community, the contents of this rule are changed by the rules, polygamous marriages without the approval of the Religious court can first be registered with the condition that the man in question first pays a fine as punishment for his conduct of polygamy without the court's permission. The country that first made amendments to this article was Kelantan in 1985, Selangor in 1989, Negeri Sembilan 1991, Penang in 1994. In 1994, Wilayah Persekutuan then joined in amending article 123 of the Deed 303. In addition to the increasingly relaxed requirements for polygamy, the 1994 Amendment also added a 55A issue that legalized the termination of marriage through divorce pronounced outside the court. Of course, this 1994 amendment received a lot of criticism from women's organizations in Malaysia. Because, the results of this amendment are considered to have degraded the results that have been achieved by the original Act of 1984 .

Until the 2000s, the Islamic family law used in the states in Malaysia, including the territories of the Alliance, was actually still an old Islamic family law with several amendments. However, there are still articles that are not 
uniform. The results of the 176th Majlis King's Assembly of the Majlis King's Assembly on August 1, 1997 and the 188th Assembly on March 22, 2001, agreed to uniform the Islamic family law. Almost all existing Islamic Family Laws have undergone significant changes towards alignment and unity of material. Regional Islamic Family Law Partnership is the model referred to for this uniform effort. Thus, almost all states have referred to the 1984 Islamic Territorial Family Law resulting from the 1994 Amendment.

In 2005, an amendment draft was compiled on the Act of 1984 Islamic Family Law that had been applied. The contents of the 2005 draft are basically a continuation of the process of uniforming Islamic family law in Malaysia. The emergence of this amendment draft gave rise to a wave of protests from women's rights advocacy groups because the substance of the amendment was considered to be increasingly discriminating against women. Among the draft that are considered discriminatory against women are first, Section 23 on polygamy. (a) This section is considered to make it easier for husbands to do polygamy, because husbands only need to prove to the Court why the new marriage needs to be carried out. (b), Provisions that a husband may demand part of the first wife's property if the husband is polygamous. (c) Existing wives are required to choose whether they are looking for a living or a property because in the settings use the "OR" clause. Secondly, (d) Section 53 concerning article that allows the husband to avoid paying compensation to his wife, and Section 108 about the prohibition on the use of the wife/husband's own assets (orders to abstain from the search for property). This section allows the husband to get a court order to prevent the wife from using her property.

On December 22, 2005, the State Council agreed and approved the 2005 Pindaan Draft. However, due to the large number of protests from the community, especially from women's activist groups, the government deemed it necessary to revise the clauses which were seen as detrimental to women. The Islamic Family Law for the Alliance Area (pindaan) was finally ratified by Deed A1261 of 2006. The draft Deed was approved by the King on January 11, 2006 and was published in Warta, February 2, 2006. However, this has not yet been implemented. Therefore, the current Islamic family law in the states in Malaysia is still based on the Act of the Islamic Family Territory of the 1984 Amendment 1994.

Thus, the aim of reforming Malaysian marriage law is to unify marriage law and improve the status of women. However, the aim of improving the status of women has been tug-of-war because there is always an effort to amend the substance of the reformation which is "considered" contrary to the sharia law such as the loosening of polygamy and the recognition of divorce outside the court which has been stipulated in the Act of the 1984 Alliance territory.

The contents of the reform of Islamic women's rights in Malaysian marriage law are as follows:

a. The right to be asked for approval if you want to be married.

b. The right to only be married if it is old enough is 18 years for men and 16 years for women.

c. Right to dowry.

d. The right to enter into a marriage agreement.

e. to earn a livelihood from the husband.

f. The right to earn a living and good relationships in the household even though there is a husband and wife dispute.

g. The right to file a divorce to the Sharia Court.

$\mathrm{h}$. The right to demand punishment for the husband's negligence in carrying out his obligations

i. The right to mut'ah to unilateral divorce.

j. The right to livelihood during the iddah period.

$\mathrm{k}$. The right to care for children up to the age of 7 years for men and 9 years for women.

1. The right to a small amount of property depends on how much the contribution in obtaining the property

$\mathrm{m}$. His rights to a special part of inheritance

\subsection{Comparison of Women's Rights Reform in Indonesian and Malaysian marriage law. \\ 4.3.1Similarities and differences}

Tahir Mahmood defines reform of Islamic family law with point of departure from conventional (classic) fiqh to modern legislation. When viewed from the concept, of course all the classical fiqh provisions that are adopted in the legal codification in modern times are included in the reformed category. In this case, Indonesia and Malaysia belong to the category of Islamic countries that have systematically reformed their marriage law in the form of a law namely the Republic of Indonesia Law No. 1 of 1974 concerning Marriage and Acts of the Regional Islamic Family Law of the Alliance 1984. Reform of women's rights in Indonesian and Malaysian marriage law can be seen from four aspects, namely:

First, aspects of paradigm.

Indonesia and Malaysia are two neighboring Malay nations, which from the beginning were influenced by the Syafi'i school dominantly so that the Syafi'i schools of jurisprudence generally become references in family law in both countries. Contact with Malay customs causes several aspects of Islamic law to be influenced by it such as in the case of search assets to the distribution of inheritance. In addition, contact with colonialism led to the 
modernization of marriage law both in terms of codification and substance of material related to regulation and administration. In general, these updates are aimed at: Unification of marriage law, improving the status of women and in response to the development and demands of the times. Here is seen a compromise of Islamic law with the customs of community culture in accordance with the rules of fiqh or Islamic legal theory "al-adatu muhakkamah" (custom can become Islamic law).

Second, aspects of the method

Reform of women's rights in Indonesian and Malaysian marriage law uses the same method in the renewal process. That is, the first, the intra-doctrinal method of reform or renewal by still referring to the conventional concept of jurisprudence which still revolves around the opinions of the imam of the good school in the way of takhayyur namely choosing the view of one of the fiqh scholars, including the ulama outside the dominant school. Takhayyur can also be substantially called tarjih, namely choosing one of the different opinions based on a more appropriate or stronger (rajih) view, or even in the Talfiq way, which is to combine a number of ulama opinions (two or more) in establishing a single law problem. This method can be seen in the arrangement regarding the bride's consent to the prohibition on marrying minors (limiting the minimum age of marriage skills). Second, the extra doctrinal reform method, which in principle no longer refers to the conventional concept of jurisprudence or comes out of the various opinions of Imam Mazhab. Either by way of reinterpretation of the texts of the Qur'an and the sunnah of the Prophet Muhammad SAW or through siyasah syar'iyyah or legal politics that is the policy of the authorities to implement regulations that are beneficial to the people and not against the principles of sharia, such as about making divorce difficult, narrowing polygamy to criminalizing marriage law violations.

Third, the Principles aspect.

Along with the demands of the times, the two countries are trying to adjust their marriage law to the principles of gender equality and recognition of human rights. It is seen that the laws of Indonesia and Malaysia try to position women in a position that is more equal to men and give wider rights when compared to the concept of traditional fiqh, which places the husband in full and absolute position and power in the household and wife who only become a servant at the husband's house.

Fourth, aspects of practice.

It's just that in the process of reform, there is a tendency for Indonesian marriage law to become more moderate and even tend to be liberal. There is a desire to further expand women's rights in marriage such as the ability to become guardians and marriage witnesses, the elimination of sirri marriage to the elimination of polygamy. However, although in plain view it looks as if it is far from the teachings of Islam (classical fiqh) but in principle, the renewal of marriage law is in line with the objectives of Islamic law (maqashid al-Shari'ah). Whereas the amendment process in Malaysia even sought to loosen the polygamy permitting requirements to the recognition of divorce outside the court which in practice often harmed the wives. Malaysia still adheres to the understanding that Islamic marriage law cannot be changed. So that if there is a renewal for the benefit of the people, the renewal is rejected because it is considered not to teach Islam.

\subsubsection{Advantages and Weaknesses}

Regarding the reform of women's rights, Indonesian marriage law is superior in the recognition that Indonesian women have equal positions with husbands both in the household, community and before the law. However, the reform of women's rights has several weaknesses, first, the KHI which is the reference of judges is only in the form of Presidential Instruction which does not have a position in the hierarchy of the Republic of Indonesia legislation. second, there is no legal sanction for violations of women's rights in marriage. Even if there are penalties stipulated in the provisions of Government Regulation No. 9 of 1975 related only to administrative matters and even then with a very low nominal value of Rp. 7,500,-, it is too light when measured by the value of money today. Third, Marriage Law (UUP) and KHI have expired and have not been able to accommodate some family law issues that developed in modern times such as the relevance of the ideal age of marriage, sirri marriage, mut'ah marriage, marriage via skype, underage marriage, up to the number of women who become heads of households because a husband who does not carry out his obligations as a husband is good because he deliberately is not responsible, sick or dies.

On the other hand, Malaysian marriage law is superior because it has a clear violation sentence. According to UUKI Malaysia, husbands who violate the rights of the wife can be subject to a fine of up to 1000 ringgit (around Rp.3,000,000,-) or a maximum of 6 months or a second prison at the same time. Even though the punishment is too light so it does not deter. It can be said that the Malaysian UUKI is half-hearted in improving the status of women because it provides opportunities for polygamy without permission and divorce outside the court to be recognized and registered under the state law with the condition of first paying a fine or serving a prescribed sentence. This means that legal practices that tend to harm women are still permitted. Thus, Malaysian marriage law is more aimed at administrative order than improving the status of women.

\section{Conclusion}

The marriage laws of Indonesia and Malaysia have given women a more equal position with men, as well as 
providing various rights that were never accepted by Muslim women in the classical period as contained in traditional fiqh books. In the marriage laws of Indonesia and Malaysia, the magnitude of the influence of Malay customs and modern culture is seen in the renewal of Islamic law in Indonesia and Malaysia. However, when viewed from a human rights perspective and gender equality, Indonesian and Malaysian Islamic law has not fully provided protection against the establishment of a just law for women in the country. This is influenced by the conception of male and female relations in Islam adopted by Muslim communities in both countries.

Because of that, it is very important and urgent to change the perspective of the majority of Muslims that the changes to Islamic family law is something that is indeed permissible and very necessary for the maintenance of the maqhasid as-syari'ah or the purpose of Islamic law so that any changes made to improve the condition of Muslims, especially women, are not considered to deviate from Islamic teachings.

\section{References}

Abdullah Yusuf Ali. (1993). Quran Terjemah dan Tafsirnya. translated by Ali Audah. Pustaka Firdaus, Jakarta. Abdul Hadi Mutohhar. (2003). Pengaruh Mazhab Syafii di Asia Tenggara. Various Sciences, Semarang.

Abd. Jalil Borham. (2002). Majalah Ahkam Johor Latar Belakang, Pelaksanaan dan Komentar. Malaysia University of Technology, Kuala Lumpur.

Abdul Rahman Haji Abdullah. (1997). Pemikiran Islam di Malaysia. Gema Insani Press, Jakarta.

Abdul Manan. (2006). Reformasi Hukum Islam di Indonesia. Raja Grafindo Persada, Jakarta.

Abdul Kadir Haji Muhammad. (1996). Sejarah Penulisaan Hukum Islam di Malaysia. Language and Library Board, Kuala Lumpur.

Abdul Aziz Dahlan. (1996). Ensiklopedi Hukum Islam. Ichtiar Baru Van Hoeve, Jakarta.

Ahmad Mohamed Ibrahim. (1997). Pentadbiran Undang-Undang keluarga Islam di Malaysia. Malaysian Islamic Understanding Institute, Kuala Lumpur.

Amiur Nuruddin and Azhari Akmal Tarigan. (2004). Hukum Perdata Islam di Indonesia. Raja Grafindo Persada, Jakarta.

Amir Syarifuddin. (2007). Hukum Perkawinan Islam di Indonesia; Antara Fiqh Munakat dan Undang-undang Perkawinan. Kencana, Jakarta.

Asghar Ali Engineer. (1994). Hak-hak Perempuan dalam Islam. Bentang Budaya, Yogyakarta.

Baharuddin Ahmad. (2008). Hukum Perkawinan Indonesia; Analisis Kesejarahan dan Metodologi. Syariah Press, Jambi.

Dedi Supriyadi. (2010). Sejarah Hukum Islam; dari Kawasan Jazirah Arab sampai Indonesia. Pustaka Setia, Bandung.

Faculty of Law at the University of Malaya. (1988). Makalah Undang-Undang Menghormati Ahmad Ibrahim. Ministry of Education Malaysia, Kuala Lumpur.

FK3. (2001). Wajah Baru Relasi Suami Isteri; Telaah Kitab 'Uqud al-Lujjain. LkiS, Yogyakarta.

Harun Nasution. (2011). Pembaharuan dalam Islam: Sejarah Pemikiran dan Gerakan. Month

J.N.D. Anderson. (1994). Hukum Islam Di Dunia Moderen (Law Reform in the Muslim World). Transfer of Machnun Husain, Cet. First. Tiara Wacana, Yogyakarta.

Josep Schacht. (1985). Pengantar Hukum Islam, translated by the Palembang Raden Fatah IAIN Team. Directorate General of Islamic Binbaga, Ministry of Religion, Jakarta.

John Rawls. (2006). Teori Keadilan. (ATheory of Justice) translated by Uzair Fauzan and Heru Prasetyo Student Library, Yogyakarta.

Khoiruddin Nasution. (2013). Hukum Perdata (Keluarga) Islam Indonesia dan Perbandingan Hukum Perkawinan Di Dunia Muslim. Cet. 1st. Acamedia and Tazzafa, Yogyakarta.

Khoiruddin Nasution. (2002). Status Wanita Di Asia Tenggara: Studi Terhadap Perundang-Undangan Perkawinan Muslim Kontemporer Di Indonesia Dan Malaysia. Inis, Jakarta.

Lili Rasjidi. (1991). Hukum Perkawinan dan Perceraian di Malaysia dan Indonesia. Teens Rosdakarya, Bandung. Masdar F. Mas'udi. (2000). Islam dan Hak-hak Reproduksi Perempuan, Mizan, Bandung

M. Atho 'Mudzhar and Khoiruddin Nasution, (Ed.). (2003). Hukum Keluarga di Dunia Islam Modern. Cet. I, Ciputat Press, Jakarta.

Mardani. (2011). Hukum Perkawinan Islam Di Dunia Islam Modern. Edition I, Cet. I, Graha Ilmu, Yogyakarta.

Marzuki Wahid and Rumadi. (2001). Fiqh Mazhab Negara: Kritik Atas Politik Hukum Islam di Indonesia. LkiS, Yogyakarta.

Mahsun Fuad. (2013). Hukum Islam Indonesia; dari Nalar Partisipatoris hingga Emansipatoris. LKIS, Yogyakarta.

M.B. Hooker. (1992). Undang-undang Islam di Asia Tenggara. Language and Library Board, Kuala Lumpur.

Michael Bogdan. (2010). Pengantar Perbndingan Hukum, translated by Dirta Sri Widowatie. Media Nusa, Bandung.

Peter Mahmud Marzuki. (2005). Penelitian Hukum. Kencana Prenada Media, Jakarta 
Peter De Cruz. (2003). Perbandingan Sistem Hukum Common Law, Civil Law and Socialist Law. Nusamedia, Bandung.

Sudirman Tebba.(1993). Perkembangan Mutakhir Hukum Islam di Asia Tenggara Studi Kasus Hukum Keluarga dan Pengkodifikasiannya. Cetakan I. Mizan, Bandung.

Sulaiman Abdullah. (1996). Dinamika Qiyas dalam Pembaharuan Hukum Islam: Kajian Konsep Qiyas Imam Syafi'i. Ilmu Jaya Guidelines, Jakarta.

Tahir Mahmood. (1972). Family law Reform in The Muslim World. The Indian Law Institute, New Delhi.

Tan Sri Datuk Ahmad Ibrahim. (1999). Undang-undang Keluarga Islam di Malaysia. Malaysian Law Journal Sdn Bhd, Kuala Lumpur.

\section{Journal / Paper / Thesis}

Ahmad Hidayat Buang. (1997). " Reformasi Undang-undang Keluarga Islam ", Syari'ah Journal, Volume 5.

Bambang Sutiyoso. (2000). " Kemandirian Hakim dan Implikasinya Terhadap Penegakan Hukum ", Jurnal Penelitian Logika-Logika, Hipotetiko. Volume 3. Number 4. Research Institute for Indonesian Islamic University, Yogyakarta.

Ida Sugiarti. (2010). " Perbandingan Hukum Informed Consent Indonesia dan Amerika", Jurnal Syiar Hukum, FH Unisba, Vol. XII, No.3.

Divine Kurnial. (2001). " Emansipasi Wanita menurut Qasim Amin", dalam jurnal Perempuan, Agama, dan Jender. Vol. 1.

Lama Abu Odeh. (2004). " Modernizing Muslim Family Law: the Case of Egypt.Vanderbilt Journal of Transnational Law, vol. 37.

Majid Khadduri. (1978). "Marriage in Islamic Law: The Modernist Viewpoints", The American Journal of Comparative Law, No.26.

Nasaruddin Umar. (2001). " Metode Penelitian Berperspektif Jender tentang Literatur Islam”, Al-Jami “ah Journal of Islamic Studies, No. 64.

Rahimin Affandi Abdul Rahim, Paizah Ismail and Norhayati Mohd. Dahlan. (2008). " Reformasi Undang-undang Keluarga Islam di Malaysia: Suatu Analisis Terhadap Gagasan Konsep Fiqh Semasa ", Syari'ah Journal 16 (2).

Sharifah Munirah al-Attas. (2007). "The Nature of Ottoman-Aceh Relations in the 16 and 17 Centuries: Commercial, Religions and Military Connection. Jurnal al-Shajarah, vol. 12

Sharifah Suhana Ahmad. (1999). "Malaysian Legal System". Malayan Law Journal. Kuala Lumpur.

Suwaid Tapah. (2003). " Harta Sepencarian dan Wang Simpanan: Suatu Perbincangan dari Sudut Sumbangan Secara Tidak Langsung ". Syariah Journal 11, (2).

\section{Legislation}

Act No.1 of 1974 concerning Marriage

Government Regulation Number 9 of 1975 concerning the Implementing Regulation of Act No.1 of 1974

Presidential Instruction No.1 of 1991 concerning Compilation of Islamic Law

The Deed of the Wilayah Persekutuan Islamic Family Law 1984

The Enactment of the Melaka State Islamic Family Law No. 12 of 2002 